\title{
What Constitutes a Diligent Search Under Present and Proposed Orphan Work Regimes?
}

\author{
David R. Hansen, Gwen Hinze and Jennifer Urban*
}

\section{Introduction}

Numerous legal regimes or proposals have been devised to address the problem of whether or under what circumstances in-copyright works can be made available if the works are "orphans", because their rights holders are unknown or cannot be found. A common feature is a requirement that a prospective user make a diligent search for the rights holder. This White Paper complements an earlier one on orphan work searches which considered who would be expected to conduct a search. ${ }^{1}$ The present White Paper focuses instead on different conceptions about what a diligent search might consist of. It does not offer a normative assessment of what "diligent search" should mean. Rather, it intends to provide information about various approaches to this concept to aid in reasoned conversations about this concept.

As we observed in the earlier paper, search requirements under the existing set of orphan works proposals differ across at least three factors: (1) who must participate in the search process; (2) the nature and extent of the search required; and (3) the types of resources, tools, registries or other information sharing mechanisms required or allowed in completing a search. This paper covers existing orphan works proposals' approaches to the second and third factors. It explains, for example, required standards for searches, such as "reasonable diligence"; the resources that searchers may, or must, consult; and relevant search documentation and registration requirements. We also highlight the areas in which proposals have failed to define search requirements in a manner that is actionable for those who are responsible for conducting the search, and explores mechanisms for providing greater guidance and legal certainty.

\footnotetext{
${ }^{*}$ About this Paper: This white paper is the fifth in a series from the Berkeley Digital Library Copyright Project, an effort organized by Berkeley Law professors Pamela Samuelson, Jason Schultz, and Jennifer Urban. The project aims to investigate copyright obstacles facing libraries and other like-minded organizations in their efforts to realize the full potential of making works available digitally. More information can be found on the project's website, available here: http://www.law.berkeley.edu/librarycopyright.htm.

For more information, please contact David Hansen at dhansen@law.berkeley.edu.

${ }^{1}$ David R. Hansen, Gwen Hinze and Jennifer Urban, Orphan Works and the Search for Rightsholders: Who Participates in a "Diligent Search" for Rightsholders Under Current and Proposed Regimes (White Paper No. 4, Berkeley Digital Library Copyright Project, 2013), http://ssrn.com/abstract=2208163.
} 


\section{Diligent Search Under Present and Proposed Orphan Works Regimes}

We have identified four categories of approaches to defining the nature of the search; these categories guide the discussion below:

(1)Under the first category, a user is expected to independently apply a given search standard, such as "reasonably diligent search," but allows for the development of minimum requirements or voluntary or government-sanctioned guidelines;

(2) Under the second category, the user also applies a given search standard; however, the user's search then requires approval or review by a central administrative authority before the work can be used. This category includes the approach taken in Canada and several other jurisdictions.

(3) The third category includes systems that require a search by a rights licensing entity, such as a collective management organization, following one of a variety of search standards. The entities covered under this category are often subject to a statutory regime or fiduciary duty to find rightsholders in order to distribute collected funds.

(4) The fourth category includes hybrid systems that combine different approaches to different types of uses or at different stages in the search. This includes regimes that incorporate different mechanisms for bulk uses, such as mass digitization, and individual uses of orphan works, such as the differentiated mechanism that is presently being proposed in the United Kingdom. This category also includes private efforts to develop search guidelines, such as community-developed best practices, in the absence of an overarching statutory or regulatory scheme.

\section{Independent User Search Standard, such as a "Reasonably Diligent Search"}

a. US Copyright Office Proposal

In its 2006 Report on Orphan Works, ${ }^{2}$ the U.S. Copyright Office recommended a remedy limitation approach whereby a user who had first performed a "good faith, reasonably diligent search to locate the owner," 3 (but had located none) would fall within a statutory safe harbor, shielded from monetary damage awards and insulated in some ways from injunctive relief. ${ }^{4}$ The

2 REgister OF COPYRIGHTS, REPORT ON ORPHAN WORKS 127 (2006) (legislative proposal text), http://www.copyright.gov/orphan/orphan-report.pdf.

${ }^{3} I d$. at 127 (proposed statutory text). The proposal would also require that throughout the use, the user provide attribution to the author and copyright owner whenever possible and appropriate under the circumstances. $I d$.

${ }^{4} I d$. A user would be insulated from full injunctive relief in cases where the user had recast, transformed or adapted the original work, but would be required to pay "reasonable compensation" to the rightsholder should she come forward and would have to provide attribution to author and copyright owner. Id. (proposed ऽ 514(b)(2)(A)-(B)). 


\section{Diligent Search Under Present and Proposed Orphan Works Regimes}

Office envisioned that users would conduct independent searches based on this standard ${ }^{5}$ before using the work in question. ${ }^{6}$ Should an owner emerge and contest in court the adequacy of the search, the user would bear the burden of proving that the search actually was reasonably diligent. ${ }^{7}$ Similarly, subsequent users would be responsible for establishing the adequacy of their own search. ${ }^{8}$

Based on fears that a rigid or overly specific standard would quickly become unworkable, ${ }^{9}$ the Office did not define "good faith, reasonably diligent search to locate the owner." However, the Office did offer some guidance as how to construe the terms. For example, the Office stated that the term "locate" should be construed to mean "identify an address to which a request for permission to use the work can be sent." 10 The Office also explained that "good faith" was a minimum requirement of any search, intended to safeguard against superficial searches conducted as a pretext for exploiting the work. ${ }^{11}$

In terms of the "reasonably diligent" standard itself, the Office identified several factors that would influence whether that standard was met in a given situation. These factors were:

- The amount of identifying information on the copy of the work itself, such as an author's name, copyright notice, or title. ${ }^{12}$ If the work had no identifying information on it at all, the requirements for search would be lower (except if there was evidence that such information had been stripped from the copy);

- Whether the work had been made available to the public. ${ }^{13}$ If the work had not been published or otherwise made available or the user could reasonably conclude that the author

${ }^{5}$ Id. at 72 .

${ }^{6} \mathrm{Id}$. at 127 (applying the recommended provision's safe harbor only if the search was conducted "prior to the commencement of the infringement').

${ }^{7}$ Id. at 96.

${ }^{8} I$ d. at 97 . Because it might be reasonable under the circumstances for a second user to rely on a prior search by a prior user, the Office did not recommend any per se rule preventing or permitting “one user's 'piggybacking' on another's search." Id.

${ }^{9} \mathrm{Id}$. at 98; see also id. at 109 ("One concern we had about developing such binding criteria is that invariably it would be incomplete and outdated quickly, as new technologies and sources of information are developed over time.”)

${ }^{10} I d$. at 97 .The Office excluded from this definition of "locate" those situations where permission has been sent to an address but the searcher receives no response from the owner. Id. The office did note, however, that "in very limited situations the failure of an individual who is believed to be an owner to respond to a permission request might be relevant to the ultimate question of whether the search has, in fact, located the owner." Id. at 97 n.350.

${ }^{11} I d$. at 98 .

${ }^{12}$ Id. at 99-100.

${ }^{13} \mathrm{Id}$. at 100-02. 


\section{Diligent Search Under Present and Proposed Orphan Works Regimes}

was still alive, she would have to do more to satisfy the diligent search requirement than if the work was published or if the author was reasonably believed to be dead;

- The age of the work, or the dates on which it was created and made available to the public. ${ }^{14}$ The older the work, the more likely that information attached to the copy is out of date, and therefore less reasonable to require extensive searches based on that information;

- Whether information about the work can be found in publicly a vailable records, such as the Copyright Office records or other resources. ${ }^{15}$ If such information is readily available, the user would be expected to consult it;

- Whether the author is still alive, or the corporate owner still exists, and whether a record of any transfer of the copyright exists and is available to the user; ${ }^{16}$

- The nature and extent of the use, such as whether the use is commercial or noncommercial, and how prominently the work figures into the activity of the user; ${ }^{17}$

The Copyright Office Report discussed, but did not resolve how, exactly, those factors should be implemented in searches in practice. ${ }^{18}$ The Office considered a system in which the Copyright Office would create, through the rulemaking process, regulations that define what "reasonably diligent search" means for specific sectors. ${ }^{19}$ That idea was rejected by the Office, however, in part because many commenters pushed for an informal, voluntary process, ${ }^{20}$ which, they argued, would result in a more collaborative discussion and more useful guidelines. In addition, the Office cited fears of technological lag, noting that if it did create such binding criteria "invariably it would be incomplete and outdated quickly." 21

\section{b. Proposed US Orphan Works Legislation}

The U.S. Copyright Office recommendation spurred the development of three separate orphan works bills, all of which required the same basic "good faith, reasonably diligent" search for owners. With respect to search, the Orphan Works Act of $2006^{22}$ made three modifications to the original 2006 Copyright Office Report framework. First, it required that prior to the use of the work,

${ }^{14} I d$. at $102-03$.

${ }^{15} \mathrm{Id}$. at $103-06$.

${ }^{16} I d$. at $106-07$.

${ }^{17}$ Id.at $107-08$.

18 Id. at 108.

${ }^{19} \mathrm{Id}$. at 109.

${ }^{20} \mathrm{Id}$.

${ }^{21} I d$.

22 H.R. 5439, 109th Cong. (2006). 


\section{Diligent Search Under Present and Proposed Orphan Works Regimes}

the searcher document the search in a way that would satisfy judicial scrutiny. ${ }^{23}$ Second, the bill attempted to clarify the "reasonable diligence" requirement by defining it both positively and negatively: the bill provided that a search is " 'reasonably diligent' only if it includes steps that are reasonable under the circumstances to locate that owner in order to obtain permission for the use of the work." ${ }^{24}$ Conversely, the bill provided that a search "is not 'reasonably diligent' solely by reference to the lack of identifying information . . . on the copy of the work or phonorecord." ${ }^{25}$ Third, the bill created a set of minimum search requirements, stating that searchers must ordinarily consult a set of resources to be maintained by the Copyright Office, such as its own copyright records, industry guidelines, best practices, and other relevant documents. ${ }^{26}$

In 2008, Congress considered two orphan works bills, the Orphan Works Act of 2008, in the House, and the Shawn-Bentley Orphan Works Act of 2008, in the Senate. Both bills built on the changes made in the 2006 bill, and added several more. First, both bills clarified the burden of proof- "preponderance of the evidence"- that a user must meet when defending his reliance on the remedy limitation. ${ }^{27}$ The House bill added a requirement that users file a "Notice of Use" with the Copyright Office prior to use, ${ }^{28}$ and both bills required that users mark copies with a symbol indicating that it was being used as an orphan work. ${ }^{29}$ More directly related to the user's search responsibility, both bills provided that a search would qualify as "reasonably diligent" if the user's actions performing the search were "reasonable and appropriate under the facts relevant to the search, including whether the infringer took actions based on facts uncovered by the search itself." 30 Additionally, the searcher must have conducted the search at a time "reasonably proximate" to the

${ }^{23} I d$., Sec.2 (proposed $\left.\int 514(\mathrm{a})(1)(\mathrm{A})(\mathrm{i})\right)$.

${ }^{24} I d$., Sec. 2 (proposed $\left.\$ 514(\mathrm{a})(2)(\mathrm{B})(\mathrm{i})(\mathrm{I})\right)$.

${ }^{25} \mathrm{Id}$., Sec. 2 (proposed $\left.\ 514(\mathrm{a})(2)(\mathrm{B})(\mathrm{i})(\mathrm{II})\right)$;

${ }^{26} \mathrm{Id}$., Sec. 2 (proposed $\left.\int 514(\mathrm{a})(2)(\mathrm{B})(\mathrm{ii})\right)$. The bill also provided that "A reasonably diligent search includes use of reasonably available expert assistance and reasonably available technology, which may include, if reasonable under the circumstances, resources for which a charge or subscription fee is imposed." Id., Sec. 2, (proposed \514(a)(20(B)(iii)).

27 H.R. 5889, 110th Cong., Sec. 2 (2008) (proposed \514(b)(1)(A)(i)); S. 2913, 110th Cong. Sec. 2 (2008) (proposed $\left.\int 514(\mathrm{~b})(1)(\mathrm{A})(\mathrm{i})\right)$.

${ }^{28}$ H.R. 5889, 110th Cong., Sec. 2 (2008) (proposed \514(b)(1)(A)(ii)).

${ }^{29}$ Id. Sec. 2 (proposed \ 514(b)(1)(A)(iv)); S. 2913, 110th Cong. Sec. 2 (2008) (proposed $\left.\ 514(\mathrm{~b})(1)(\mathrm{A})(\mathrm{iii})\right)$. This symbol could indicate both that the use was unpermissioned, and alert a copyright owner who had not been found to could come forward, claim the work, and negotiate a license fee.

${ }^{30}$ H.R. 5889, 110th Cong., Sec. 2 (2008) (proposed \514(b)(2)(A)(ii)(I)); 


\section{Diligent Search Under Present and Proposed Orphan Works Regimes}

commencement of the use, ${ }^{31}$ and under the Senate bill, would need to consult "reasonably available" sources of copyright authorship and ownership information, use "appropriate" technology tools, and "reasonable" expert assistance. ${ }^{32}$ Moreover, searchers would have to follow certain best practices (or "Recommended Practices") for searches, which the Copyright Office would be charged with maintaining. ${ }^{33}$ Both bills seemed to contemplate that these guidelines would be created through a development process at the Copyright Office, and would incorporate best practices or other resources developed by private organizations. ${ }^{34}$ Finally, both bills contained a special carve-out for visual works such as photographs, providing that the remedy limitation would not apply to those works until the Copyright Office first certified the existence and public availability of databases that can help identify owners of these works. ${ }^{35}$

Ultimately, while the Senate did pass its version of the 2008 bill, ${ }^{36}$ Congress as a whole did not enact any of the orphan works bills it considered.

\section{c. EU Orphan Works Directive}

On October 25, 2012, the European Union adopted a Directive on Orphan Works requiring that EU Member States create an exception in their national copyright law to accommodate some uses of orphan works. ${ }^{37}$ Like the U.S. Copyright Office proposal and proposed legislation, the Directive provides that works and phonograms shall be considered to be orphan works if all the rightsholders in a work are not identified and located despite a "diligent search" having been carried

${ }^{31}$ Id. Sec. 2 (proposed \514(b)(2)(A)(ii)(III)); S. 2913, 110th Cong. Sec. 2 (2008) (proposed \514(b)(2)(A)(i)).

32 S. 2913, 110th Cong. Sec. 2 (2008) (proposed \514(b)(2)(A)(ii)).

33 H.R. 5889, 110th Cong., Sec. 2 (2008) (proposed \514(b)(2)(A)(ii)(II)); S. 2913, 110th Cong. Sec. 2 (2008) (proposed \514(b)(2)(A)(iii)). The Copyright Office would be required to "maintain and make available the public, including through the Internet, current statements of best practices for conducting and documenting a search." ${ }^{3}$ H.R. 5889, 110th Cong., Sec. 2 (2008) (proposed \514(b)(2)(B)(i)); . In addition, the Copyright Office was charged with facilitating the creation of a database of pictoral, graphic and sculptural works. Id., Sec. 3.

34 S. 2913, 110th Cong. Sec. 2 (2008) (proposed \514(b)(2)(B)(i)).

35 H.R. 5889, 110th Cong., Sec. 4 (2008) (effective date); S. 2913, 110th Cong. Sec. 2 (2008) (amending table of sections, effective date).

36 S. 2913, 110th Cong. (2008), http://www.gpo.gov/fdsys/pkg/BILLS-110s2913es/pdf/BILLS110s2913es.pdf (engrossed in Senate).

${ }^{37}$ Directive 2012/28/EC of the European Parliament and of the Council of 25 October 2012 on Certain Permitted Uses of Orphan Works, http://eur-lex.europa.eu/LexUriServ/LexUriServ.do?uri=OJ:L:2012:299:0005:0012:EN:PDF 


\section{Diligent Search Under Present and Proposed Orphan Works Regimes}

out. ${ }^{38}$ As described further below, the Directive supplements a standards-based approach to what constitutes a "diligent search" with some prescriptive requirements. The Directive is also far narrower in its application and scope of relief than the U.S. proposals; while the Directive requires the EU Member States to create an exception in their national copyright law, the exception member states are to implement applies only to certain types of works, ${ }^{39}$ certain types of uses ${ }^{40}$ - excluding, for example, any follow-on derivative works — made by publicly accessible libraries, educational institutions, museums, archives, film and audio heritage institutions, and public broadcasting institutions. It is further limited to particular types of EU works in these institutional collections, and uses must be made in order to achieve aims related to the institutions' public interest missions. ${ }^{41}$ The

${ }^{38} \mathrm{Id}$., Articles 2(1) and 3. It is also worth mentioning that libraries and publishers in the EU have privately agreed on a set of principles that apply to voluntary collective licensing agreements for mass digitization of collections that include out of commerce books, journals and literary works. The category of "out of commerce" works is broader than "orphan works" because a rightsholder of an out of commerce work may be known and locatable, but the work may not be in print or actively circulating in the market. In September 2011, EU libraries and publishers and the collective management organization IFRRO, the International Federation of Reprographic Rights Organization, entered a Memorandum of Understanding (MoU). See Memorandum of Understanding (Sept. 20, 2011), http://ec.europa.eu/internal market/copyright/docs/copyright-infso/20110920-mou en.pdf. In terms of search, the framework agreement is relatively open-ended, but does provide that " $t$ the determination by the parties of whether a work is out of commerce or not shall be conducted according to the customary practices in the country of first publication of the work. Each Agreement shall stipulate the steps that have to be taken in order to verify whether a work is out of commerce." Id. This approach is similar to other private agreements such as the Google Book Search Settlement, which provided that Google would take "commercially reasonable" steps to determine the commercial availability of works in the Google Books corpus (and therefore, identity and location of rightsholders). See The Authors Guild Inc. v. Google, Inc., Case No. 05 CV 8136-DC, Amended Settlement Agreement $₫ 3.2$ (Nov. 13, 2009).

39 The Directive applies to published textual works including books, journals, newspapers and magazines, first published in a EU member state, and to cinematographic or audiovisual works and phonograms first broadcast in an EU member state that are held in relevant EU institutions' collections, and to those types of works produced by EU public service broadcasting organizations prior to December 31, 2002, and held in their archives. Id., Art. 1. The Directive also applies to works that have not been published or broadcast, where they have been made publicly accessible by the relevant EU institutions with the consent of the rightsholder. Id., Art. 1(3) (provided that it is reasonable to assume that the rightholders would not oppose the uses permitted under Art. 6 of the Directive). The Directive does not apply to stand-alone photographs, but does apply to photographs embedded or incorporated into other covered works. Id., Art. 1(4).

40 The Directive permits the cultural organizations to which it applies to make two types of uses of identified orphaned works in their collections: reproduction including "for the purposes of digitization, making available, indexing, cataloguing, preservation or restoration", and making available. Id., Art. 6. In its final form, the Directive is not limited to non-remunerative use. The beneficiary organizations may generate revenue from permitted uses provided it is used exclusively to defray their costs of digitizing orphan works and making them available to the public. This can be done through private-public partnerships agreements.

${ }^{41} \mathrm{Id}$., Article 1. The U.S. Copyright Office considered and rejected suggestions that it limit its approach to a similar group of organizations. REGISTER OF COPYRIGHTS, supra note 3, at 81-81, 107. The directive is not, 


\section{Diligent Search Under Present and Proposed Orphan Works Regimes}

27 EU member states must implement the Directive's framework into their national laws by October 29, 2014. ${ }^{42}$

The Directive does not contain a detailed definition of "diligent search," but sets a minimum threshold for what constitutes a diligent search and identifies a minimum set of resources to which searchers must look. The Directive allows EU member states to specify additional sources to be consulted. The Directive requires that searches be carried out in good faith and must consult appropriate sources for the relevant category of works. ${ }^{43}$ What sources will be considered appropriate is left to EU Member States to determine in consultation with rightsholders and users. However, at a minimum, the Directive requires EU cultural institutions to search at least the sources specified in the Annex to the Directive, which include a fairly extensive set of public and privately held databases (as set out in the Annex to this paper). ${ }^{44}$ The search must consult sources that "supply information on the works" as determined in both the Directive and Member States' national law. ${ }^{45}$ The Directive also suggests, but in its final version does not require, that EU Member States refer to the more detailed sector-specific 2008 Diligent Search Guidelines developed by the EU High Level Expert Group on Digital Libraries established under the i2010 Digital Libraries initiative, ${ }^{46}$ which identify sets of databases and resources to consult when searching for owners of published books, periodicals, phonograms, and audiovisual works.

The diligent search must be carried out in the EU country of first publication or first broadcast. In the case of cinematographic and audiovisual works, where the producer has headquarters or habitual residence in an EU country, the search must be carried out there. To protect first publication, searches for owners of works that are unpublished or have not been

however, limited to non-remunerative use. The organizations covered by the Directive may generate revenues in the course of the permitted users provided that they are used exclusively for the purpose of covering their costs of digitizing orphan works and making them available to the public, ${ }^{41}$ including through private-public partnerships agreements. Id., Article 6(2), Recital 21.

${ }^{42} I d$., Art. 9.

${ }^{43} I d .$, Art.3(1).

${ }^{44}$ Id., Art. 3(2).

${ }^{45}$ Id., Recital 14.

${ }^{46}$ European Digital Libraries Initiative, Joint Report on Sector-Specific Guidelines on Due Diligence Criteria for Orphan Works, 2, http://ec.europa.eu/information society/activities/digital libraries/doc/hleg/orphan/guidelines.pdf; Memorandum of Understanding on Diligent Search Guidelines for Orphan Works (June 2008), http://ec.europa.eu/information society/activities/digital libraries/doc/hleg/orphan/mou.pdf. 


\section{Diligent Search Under Present and Proposed Orphan Works Regimes}

broadcast but have been made publicly available by an institution with the consent of the rightholder must be carried out in the country where the institution is located. ${ }^{47}$ However, the Directive has an important additional requirement, requiring users to conduct broader searches of sources in other countries, where evidence suggests that relevant rightsholder information may be found there. ${ }^{48}$ The Directive provides no further information about the level or type of evidence that would trigger the broader search obligation.

The Directive also contains strong information-sharing provisions. The Directive requires EU Member States to ensure that cultural institutions document the search that they have undertaken and the results, which will be recorded in a centralized publicly accessible online database that will be established and managed by the European Commission's Office for Harmonization in the Internal Market. ${ }^{49}$ Cultural institutions must maintain, and share via the centralized EU database, information about the institution's use of an identified orphan work, and any change of status of previously identified orphan works. ${ }^{50}$ Cultural institutions must keep a copy of the search record on file, to "be able to substantiate that the search was diligent." ${ }^{51}$ Cultural institutions must also indicate the name of any identified rightsholders in any use of a partly orphaned work. ${ }^{52}$

\section{User Search Reviewed or Approved by Central Administrative Authority}

Canada, South Korea, Japan, ${ }^{53}$ India,${ }^{54}$ and Hungary have adopted regimes under which a central government agency may grant a license to use identified orphan works after a search for

${ }^{47} I d$. , Arts. 1(3) and 3(3).

${ }^{48}$ Id., Article 3(4).

${ }^{49} I d$., Arts. 3(5) and 3(6).

${ }^{50}$ Id., Recital 16.

${ }^{51}$ Id., Recital 15.

${ }^{52}$ Id., Article 6(3).

${ }^{53}$ See Copyright Act 1970, Law No. 48 of 1970, 2009 (Japan) Arts. 67, 74; unofficial English translation at http://www.cric.or.jp/cric e/clj/clj.html.

${ }^{54}$ Copyright Act 1957 as amended by the Copyright Amendment Act of 2012 (India) at paras. 17-18, http://copyright.gov.in/Documents/CRACT AMNDMNT 2012.pdf (allowing for applications to Copyright Board for works where "the author is dead or unknown or cannot be traced, or the owner of the copyright in such work cannot be found," and directing that the Copyright Board to grant licenses for use after it has made an inquiry into the good faith and satisfied itself that the license needs to be granted after giving any owners an opportunity to be heard); 


\section{Diligent Search Under Present and Proposed Orphan Works Regimes}

rightsholders. Legislation pending in both the United Kingdom (discussed in more detail below) and the People's Republic of China would create similar schemes. ${ }^{55}$ Each of these regimes requires the prospective user to undertake a prior search for rightsholders of the work and to pay a licensing fee, which is usually held in escrow for re-appearing rightsholders. These countries' approaches differ on the search standard users must abide by and on the level of oversight exercised by the relevant administrative or judicial body.

\section{A. Canada}

Prospective users of works for which owners cannot be located may apply to the Copyright Board of Canada for a non-exclusive license to make uses of certain work. ${ }^{56}$ The Copyright Board may grant a license when "the Board is satisfied that the applicant has made reasonable efforts to locate the owner of the copyright and that the owner cannot be located."

The Canadian legislation gives considerable discretion to the administrative body, both on what constitutes "reasonable efforts" by a prospective user, and on the terms of the non-exclusive license it may grant, including remuneration. ${ }^{58}$ The Canadian Copyright Act empowers the Board to issue regulations, but the Board has not done so to date. ${ }^{59}$ However, it has given informal guidance

55 The existing UK Copyright, Patent and Designs Act 1988 permits licensing for orphan performances, but would be broadened under draft legislation currently pending before the UK Parliament. See proposed sections 116A-116D of the Copyright, Designs and Patents Act of 1988, which would be inserted by section 69 of the draft Enterprise and Regulatory Reform Bill, HL Bill 083 2012-2013, as amended by House of Lords Grand Committee on February 4, 2013, at http://www.publications.parliament.uk/pa/bills/lbill/20122013/0083/2013083.62-66.html\#jnc13 and http://services.parliament.uk/bills/2012-

13/enterpriseandregulatoryreform.html; Maria Strong, External Perspectives on the New Draft Chinese Copyright Law: Informal Comments of the U.S. Copyright Office, presentation at the Conference on New Developments in Chinese Copyright Law and Enforcement, Berkeley Centre for Law \& Technology, October 4, 2012 at http://www.law.berkeley.edu/files/bclt Panel 2 Maria Strong.ppt; Dr. Prof. Hong Xue, A User-Unfriendly Draft: 3rd Revision of the Chinese Copyright Law (April 2012), http://infojustice.org/wpcontent/uploads/2012/04/hongxue042012.pdf.

${ }^{56}$ Copyright Act of Canada, RSC 1985, c. C-42, section 77, available at http://www.canlii.org/en/ca/laws/stat/rsc-1985-c-c-42/latest/rsc-1985-c-c-42.html (allowing for the licensed use of a published work, a fixation of a performer's performance, a published sound recording, or a fixation of a communication signal.)

${ }^{57} \mathrm{Id}$.

${ }^{58}$ Jeremy de Beer and Mario Bouchard, Canada's Orphan Works Regime: Unlocatable Copyright Owners and the Copyright Board, 10 OXFORD UNIV. COMMONWEALTH L.J. 215, 230-239 (2011).

${ }^{59}$ Id., at 227. The May 2011 EU Orphan Works Impact Assessment also warned against adoption of static guidelines and the cost implications of stringent diligent search requirements, at 47-8, at:

http://ec.europa.eu/internal market/copyright/docs/orphan-works/impact-assessment en.pdf 


\section{Diligent Search Under Present and Proposed Orphan Works Regimes}

on what it considers minimum requirements for a reasonable efforts search. In practice, those familiar with the system explain that "[t]he [US Copyright Office Orphan Works Report] referenced numerous factors suggested by commentators, many of which the Board considers as a matter of course in the context of [orphan works license] applications." ${ }^{60}$ Canadian commentators also note that the Board generally expects an applicant to have consulted most of the repertoires of copyright licensing agencies, and collective societies, together with national libraries' indices, copyright offices' registration records, publishing houses and corporate records. ${ }^{61}$ As with the 2008 proposed legislation in the United States, applicants must document their searches as a necessary requirement of satisfying the Board's inquiry. ${ }^{62}$ And, like the EU Directive, a searcher would be required to extend the search beyond Canadian national borders if it is probable that the owner of the copyright would be located in another country. ${ }^{63}$

\section{B. The Republic of Korea}

The Korean Ministry of Culture, Sports, and Tourism can grant licenses for use of particular orphaned works on application by a user and payment of up-front licensing fees. For the Ministry to grant a license, an application must satisfy the Ministry that the user has been unable to identify a copyright owner, or that the copyright holder's identity is known but his or her location is unknown, despite the user having expended "considerable efforts" in accordance with specified criteria. ${ }^{64}$

Korean law specifies two minimum criteria that must be satisfied for a "considerable efforts" search. First, a prospective user must have sent a request to a copyright trust service provider (a collective management organization), or to two persons authorized to exploit the relevant work, seeking the name and address of the author, and either received a reply that that the information is not known, or else must not have received a response within one month from the date of the request. Second, the prospective user must have published a notice of inquiry in general daily

${ }^{60}$ De Beer, supra note 59, at 227.

${ }^{61} \mathrm{Id}$. at 226-28.

${ }^{62} \mathrm{Id}$. at 228. This practice is apparently scaled back from pervious requirements. "Previously, applicants were required to file an affidavit setting out precisely all of the steps undertaken to locate the copyright owner, in addition to other supporting documents. The Board has now abandoned that practice." Id.

${ }^{63} \mathrm{Id}$.

${ }^{64}$ Korean Copyright Act of 1957 (Law no. 432, as amended by Law no. 9625, April 22, 2009), Article 50, available at: http://www.wipo.int/wipolex/en/text.jsp?file $\mathrm{id}=190144$, read in conjunction with Article 18(2) of the Enforcement Decree of the Copyright Act (Presidential Decree No. 22003, Jan. 27, 2010) (Kor.), available at: http://www.wipo.int/wipolex/en/text.jsp?file $\mathrm{id}=200937$. 


\section{Diligent Search Under Present and Proposed Orphan Works Regimes}

newspapers of nationwide circulation or on the websites of the Ministry of Culture, Sports and Tourism and the Korean Copyright Commission announcing the proposed use of the work, and must not have received a response within 10 days of publication. ${ }^{65}$

\section{Japan}

Japan has adopted a compulsory licensing regime for copyrighted works that have been offered or made available to the public for a considerable period of time, and for which rightsholders cannot be found or located after "due diligence." A person who wishes to use a suspected orphan work must submit an application to the Commissioner of the Agency for Cultural Affairs, describing the proposed use of the work, including data explaining what searches were performed to try to locate the rightsholder, and other information set out in a Cabinet Order. ${ }^{66}$ The prospective user must also pay a license fee that will be held on deposit for any re-appearing rightsholders. Copies of suspected orphaned works must bear an indication that the reproduction was licensed in accordance with the Japanese orphan works provisions, and must indicate the date when the license was issued by the Commissioner of the Agency for Cultural Affairs. ${ }^{67}$

\section{Search by Collective Management Organizations}

Several countries have adopted collective licensing regimes specifically designed to facilitate access to orphan works, or are considering regimes that appear to be broad enough to cover orphan works within collections. In these regimes, the collective management organization (CMO) that administers the licensing scheme would undertake a search for rightsholders. ${ }^{68}$

\section{A. Extended Collective Licensing in Nordic Countries}

Extended Collective Licensing regimes are in operation in Hungary and the Czech Republic, and in Sweden, Norway, Denmark, Iceland, and Finland. The Nordic country ECL regimes cover primary broadcasting, cable retransmission and communication to the public of previously broadcast

${ }^{65}$ Id., Decree, Article 18.

${ }^{66}$ See Copyright Act 1970, Law No. 48 of 1970, 2009 (Japan) Arts. 67, 74; unofficial English translation at http://www.cric.or.jp/cric e/clj/clj.html.

${ }^{67}$ Id., Art. 67(3).

${ }^{68}$ For a more detailed discussion of these systems and some of the challenges associated with CMO searches for rightsholders, see the first paper in this series, Hansen, Hinze \& Urban, supra note 2, at 8-17. 


\section{Diligent Search Under Present and Proposed Orphan Works Regimes}

television programs, and certain forms of reproduction (including photocopying) for certain activities (including educational purposes in several countries) or by certain institutions. In addition, ECL regimes operate for other narrow uses of works, varying by country. ${ }^{69}$ The Nordic ECL regimes are sectoral, covering narrow uses and/or classes of works set out in the relevant legislative provisions. By comparison, in 2008 Hungary adopted an ECL regime that expressly extends authority to Hungarian CMOs to license orphan works in broader collections that they administer. ${ }^{70}$

The Nordic regimes build on existing collective management agreements that cover particular classes of works, but extend their operation via legislation to permit the CMO to represent rightsholders who are not members. This extension of authority enables the CMO to offer a license for use of an entire class of works, which in turn allows licensees to make use of works without legal liability. Non-member rightsholders' interests are protected through legislative provisions requiring CMOs to provide equal treatment to members and non-members regarding remuneration, by provisions on mediation and arbitration, and by providing rightsholders with the ability to opt out and/or seek individual remuneration. ${ }^{71}$

Because Nordic ECL regimes empower the relevant CMOs to grant licenses for use of works within a given class, the CMOs do not need to conduct searches for the identity of nonmember rightsholders before granting a license. However, by virtue of the statutory obligation to provide equal treatment to members and non-members regarding remuneration, CMOs must search for non-member rightsholders at a later time, to distribute license fee proceeds due to them.

Identifying how these regimes price licenses or uses that may include orphans, and what type of search they do in order to do so is beyond the scope of this paper. However, by way of example, Kopinor (the CMO that administers the Norwegian ECL regimes) has a Distribution Committee that determines how to make distributions. This Committee comprises of members of author and publisher organizations and others nominated by a Nominating Committee. ${ }^{72}$ In the event of a

69 JOHAN AXHAMn AND LuCIE GUIBAUlt, CROSS-BORDER EXTENDED COLLECTIVE LiCENSING: A SOLUTION TO ONLINE DisSEMINATION OF EUROPE's CULTURAl HERITAGE? 29-30 (2011), www.ivir.nl/publications/guibault/extended collective licensing.pdf; see also Press Release on signing of Bookshelf Contract between the Norwegian National Library and KOPINOR, August 28, 2012, http://www.kopinor.no/en/about-kopinor/news/online-access-to-all-norwegian-literature-from-the-20thcentury (under which 250,000 books from the 1690's, 1790's, 1890's and the 1990's will be made accessible to Internet users with Norwegian IP addresses).

70 The Hungarian system is discussed infra notes 97 to 106 and accompanying text.

${ }^{71}$ AXHAMN \& GUIBAULT, supra, note 69 at 27-28, 30.

72 Kopinor By-Laws, Articles 7.2 and 7.3., http://www.kopinor.no/en/about-kopinor/by-laws. 


\section{Diligent Search Under Present and Proposed Orphan Works Regimes}

dispute about distribution, an affected party can refer the matter to arbitration. ${ }^{73}$ In Sweden, the government has apparently engaged in a more formal review of the effectiveness of CMO distribution to outsiders. ${ }^{74}$ In addition, the Nordic ECL CMOs will be subject to further transparency requirements if the proposed EU CMO Directive (discussed below) is adopted.

\section{B. Proposed EU Directive on Collective Management Organizations}

In July 2012 the European Commission released a proposed "Directive on Collective Management of Copyright and Related Rights and Multi-Territorial Licensing of Rights in Musical Works for Online Uses". ${ }^{75}$ The draft CMO Directive contains two sets of provisions. The first deals with facilitating multi-territorial copyright licensing of musical works across EU member states. ${ }^{76}$ The second deals with governance of all collective management organizations operating in the EU. This includes CMOs that manage rights in books, journals and other categories of copyrighted and related rights works beyond musical works. ${ }^{77}$ It would impose new obligations on CMOs for timely distribution of funds received, and reporting, including publication of an annual transparency report, disclosing revenues received and paid out. ${ }^{78}$ Although not framed in the language of orphan works, these provisions would require CMOs to take measures to identify those to whom they must pay out collected fees, and raise the question of the level of effort that CMOs must make in doing so.

It is sometimes assumed that an ECL regime for orphan works does not require any search to be undertaken. ${ }^{79}$ The proposed CMO Directive highlights that this is not necessarily true. The

${ }^{73} I d .$, . Article 9.

74 AVtalad UPPHOVSRÄTT, SOU 2010:24 (2010), http://www.government.se/content/1/c6/14/33/63/a1746577.pdf (published in Swedish, apparently analyzing how effectively CMOs make payouts to outsiders).

75 Proposal for a Directive of the European Parliament and of the Council on Collective Management of Copyright and Related Rights and Multi-Territorial Licensing of Rights in Musical Works for Online Uses in the Internal Market, COM (2012) 372 Final (July 11, 2012), http://ec.europa.eu/internal market/copyright/docs/management/com-2012-3722 en.pdf.

$76 \mathrm{Id}$., Title III and Articles 36 and 40 of Title IV.

${ }^{77} \mathrm{Id}$., Titles I, II and IV.

${ }^{78} I d$., Article 20.

79 See, e.g., submission of National Library of the Netherlands, as reported in European Commission Impact Assessment on Orphan Works 16 (March 2011), http://ec.europa.eu/information society/activities/digital libraries/doc/reports orphan/anna report.pdf ("The National Library of the Netherlands has indicated clearly that a title by title search is not feasible for large scale digitisation projects which normally include thousands of right holders to possibly hundreds of thousands works. ... The library states that although it has concluded collective agreements with right 


\section{Diligent Search Under Present and Proposed Orphan Works Regimes}

CMO would have to undertake a search for rightsholders, but the costs of doing so would be deferred until after the use has been made, and rights revenue has been collected. The deferred nature of the search raises a set of interesting questions about how CMOs should set appropriate prices for licenses for collections of works that may contain a significant proportion of orphans, such as those of many large cultural institutions.

The draft CMO Directive would require EU Member States to ensure that collecting societies carry out distribution of revenue collected within 12 months from the end of the financial year within which rights revenues are collected, unless "objective reasons related to ... identification of rights, rightsholders or to the matching of information on works and other subject matter with rightsholders prevent the collecting society from respecting this deadline". ${ }^{80}$ Collecting societies can make determinations about how to use funds that have not been distributed after five years from the end of the financial year in which the monies were collected, provided that they have taken "all necessary measures to identify and locate the rightsholders" and that their members approve rules governing distribution of funds in the event of unidentified or unlocatable rightsholders. ${ }^{81}$

The draft CMO Directive provides some guidance on the standard for the search that CMOs are required to undertake for this purpose. However, unlike the 2012 EU Orphan Works Directive, the draft CMO Directive does not prescribe a set of sources that must be consulted. Instead, CMOs would be required to "undertake diligent and good faith reasonable measures to identify and locate the relevant rightholders." ${ }^{82}$ The existing national collective management arrangements for administration of musical rights within EU countries often rely on reciprocal arrangements between nationally-based CMOs that represent rightsholders from their respective countries. In the orphan works context, however, the unlocatable or unknown rightsholder would not be a member of a $\mathrm{CMO}$ and hence would not be findable by searching membership records of CMOs. To identify and locate non-members, the proposed Directive would rely on publication of notices to the public. Article 12 of the draft Directive provides that measures to identify and locate

holders, the use of potential orphan works by the library remains infringing, because this collective solution lacks a legal basis. The Scandinavian extended collective licensing regime is seen as a promising solution to the problem. ... The library advocates that the EU should introduce a Europe-wide, mandatory legal solution for both orphan works and mass-scale digitisation, which does not require a diligent search on a per-work basis.").

${ }^{80}$ Id., Article 12(1).

${ }^{81}$ Id., Article 12(2).

${ }^{82} I d$. 


\section{Diligent Search Under Present and Proposed Orphan Works Regimes}

rightsholders shall include "verifying membership records and making available to the members of the collective society as well as to the public a list of works and other subject matter for which one or more rightsholders have not been identified or located." 83 Thus, as a preliminary matter, the draft Directive seems to place the burden on rigthsholders to seek out notices that would likely be posted on the websites of the relevant national CMOs in each EU member state. By comparison, the EU Orphan Works Directive creates a centralized EU orphan works registry to facilitate streamlined searches. However, as discussed above, that Directive has a narrow scope of application and it is unclear the extent to which subsequent non-institutional users of orphan works could rely on searches first conducted by the EU cultural institutions to which it applies.

These provisions highlight a potential conflict of interest inherent in approaches that involve searches by licensing authorities. The $\mathrm{CMO}$ that is required to conduct the search for absent rightsholders may stand to gain funds that cannot be allocated to unlocatable rightsholders,

potentially creating an incentive for a CMO to be less thorough in its search procedure. ${ }^{84}$ However, the potential conflict of interest may be mitigated somewhat by the possibility of increased external scrutiny if new transparency obligations in the draft CMO Directive are adopted. In addition to its distribution obligations, the draft Directive would require all EU collecting societies to publish an annual transparency report on their website within six months of the end of the financial year, with detailed information about the annual rights revenue per category and use of works, costs of the CMO's operations, payments made to rightsholders in the preceding financial year, and "the total amount collected but not yet attributed to rightsholders, with a breakdown per category of rights managed and type of use, and indicating the financial year in which these amounts were collected." ${ }^{85}$

\section{Hybrid Approaches}

Other approaches to the orphan works problem also contemplate searches for rightsholders, but are hybrids in that they often require the searcher to conduct these searches at different times or in different ways depending on the desired use (e.g., mass digitization as opposed to single uses). In addition, several private hybrid efforts to develop search guidelines in the absence of a clear legislative or regulatory scheme incorporate a variety of search standards.

${ }^{83}$ Id., Article 12(3); Recital 15

84 See, e.g.,Thomas Riis, Collecting Societies, Competition, and the Services Directive, Journal of Intellectual Property Law \& Practice, 2011, Vol. 6, No. 7, 482, 492 note 70 (OUP).

${ }^{85}$ Draft CMO Directive, supra, note 75, Article 20 and Annex I. 


\section{Diligent Search Under Present and Proposed Orphan Works Regimes}

\section{A. Proposed UK Two-tiered Approach}

The UK Parliament is considering adopting a two-tiered orphan works regime, permitting commercial and non-commercial use of published and unpublished works. At the first tier, cultural institutions would be permitted to digitize their collections (and any orphaned works in them) through an Extended Collective Licensing regime. At the second tier, prospective users of individual or small numbers of orphan works can apply for a non-exclusive license from a central government, or government-sanctioned, agency. The first tier borrows from the ECL regimes of the Nordic countries; the second is similar to the regimes in Canada and Japan. ${ }^{86}$ In support of both, the UK is also proposing to create a national orphan works registry. A similar two-tiered approach was adopted by Hungary in 2008 (see below). ${ }^{87}$

Diligent search is a core requirement of the UK regime. A search will be required before use of a suspected orphan work either for mass digitization or individual use. At the first tier, the diligent search would be performed by the cultural institution that wishes to digitize its collection or, potentially, by a collective management organization that has applied to operate an ECL regime for the particular class of works. At the second tier, diligent searches will be performed by the user that wants to make use of an individual orphan work.

The UK proposal contemplates that a new authorizing body will be created to oversee searches and issue licenses. The new body will be tasked with issuing sector-specific guidelines for what constitutes a diligent search, which are to be developed with input from the relevant industries. The new authorizing body will not generally validate searches done by institutions or their agents that wish to engage in mass digitization via extended collective licensing. Instead, it will take a "regulatory" approach, accrediting institutions that want to register orphan works, and periodically auditing the quality of the institutions' searches and the search process on a random sampling basis. $^{88}$ The new body will have power to exclude organizations that do not continue to meet the

\footnotetext{
86 See proposed sections 116A-116D of the Copyright, Designs and Patents Act of 1988, which would be inserted by section 69 of the draft Enterprise and Regulatory Reform Bill, HL Bill 083 2012-2013, as amended by House of Lords Grand Committee on February 4, 2013, at http://www.publications.parliament.uk/pa/bills/lbill/2012-2013/0083/2013083.62-66.html\#jnc13 and http://services.parliament.uk/bills/2012-13/enterpriseandregulatoryreform.html.

87 Id

88 The UK government apparently rejected a requirement that the new body review and approve searches done by institution due to concerns raised about the Canadian experience, which was criticized in submissions as being bureaucratic, costly, and "likely to be little used". See Final Impact Assessment at 4 (July
} 


\section{Diligent Search Under Present and Proposed Orphan Works Regimes}

required standards. ${ }^{89}$

At the second tier, for applications for use of single or small numbers of orphan works by individuals and institutions, the new authorizing agency will verify the diligent search. ${ }^{90}$ The authorizing body will require details of searched databases and methods with each orphan work registration application. ${ }^{91}$ Although details are yet to be determined, it seems likely that at a minimum, a prospective user will have to search the new UK Copyright Hub, an interface to a federated collection of existing rights management databases, being developed as part of the UK Digital Copyright Exchange. ${ }^{92}$

Many of the details of how the search requirements will work in practice are yet to be determined. Draft legislation pending before UK Parliament would empower the UK Secretary of State to issue statutory regulations that will set out procedures and the details of the proposed regime. ${ }^{93}$ Issues yet to be resolved include the identity of the authorizing body that will confirm searches, whether it will be managed as a public agency or as a public-private sector partnership with collective management organizations, and whether the agency would be empowered to conduct diligent searches as a fee-based service. ${ }^{94}$ Also yet to be resolved is the extent to which recent diligent searches can be relied upon by subsequent users.

2012), http://www.ipo.gov.uk/consult-ia-bis1063-20120702.pdf.

${ }^{89}$ Id. at 3 .

${ }^{90} I d$. at 5.

${ }^{91} I d$. at 7 .

92 See IAN Hargreaves, Digital Opportunity: A Review of Intellectual Property and Growth T4.59 (2011), http:/ / www.ipo.gov.uk/ipreview-finalreport.pdf ("Tying the orphan works solution into the Digital Copyright Exchange will also provide a straightforward means of determining whether a search for the rights holder is sufficiently "diligent" - and should provide rights holders with a further incentive to join the scheme. The Exchange also offers a built in mechanism for dispute resolution, and safeguards against works becoming orphaned as discussed above.”); RICHARD HOOPER \& ROS LYNCH, COPYRIGHT WORKS: STREAMLINING COPYRIGHT LICENSING FOR THE DigITAL AGE 990 (2012) http://www.ipo.gov.uk/dcereport-phase2.pdf (report commissioned by the UK Intellectual Property Office as part of the implementation of the Hargreaves Review recommendations).

93 See proposed sections 116A-116D of the Copyright, Designs and Patents Act of 1988, which would be inserted by section 69 of the draft Enterprise and Regulatory Reform Bill, HL Bill 083 2012-2013, as amended by House of Lords Grand Committee on February 4, 2013, at http://www.publications.parliament.uk/pa/bills/lbill/2012-2013/0083/2013083.62-66.html\#jnc13 and http://services.parliament.uk/bills/2012-13/enterpriseandregulatoryreform.html.

${ }^{94}$ If the agency is constituted as a public agency, it seems likely that it would not offer a diligent search service. The UK IPO recognized that this could give rise to a conflict of interest "as there would be concern that the authorizing body [would] subsidise such searching activity with collected fees and distort private market providers for such services." 


\section{Diligent Search Under Present and Proposed Orphan Works Regimes}

\section{B. Hungary}

In 2008 Hungary adopted a two-tiered orphan works regime similar to that proposed in the United Kingdom. The Hungarian system created an Extended Collective Licensing regime for uses of works that are covered by existing collective management arrangements, and a non-exclusive and non-transferable license regime granted by the Hungarian Patent Office (HPO) for use of orphan works falling outside the scope of collective rights management, based on the Canadian system. ${ }^{95}$ Individual licenses to use orphan works are for a maximum term of five years, do not permit derivative uses of works, and may authorize both commercial and non-commercial uses. ${ }^{96}$

Applicants for an individual license from the HPO must conduct a search for rightsholders based on sector-specific guidelines as a precondition for lawfully using an orphan work. ${ }^{97}$ License applicants must attach proof of the search that they have undertaken and the fact that the search was unsuccessful, including details of "the appropriate measures in a manner that are deemed reasonable under the given circumstances and with regard to the concerned type of work and mode of use to quest the author." 98

The search measures may, depending on the circumstances, include: ${ }^{99}$

(a) Searching the register of licenses granted to use orphan works maintained by the HPO;

(b) Searching the databases of collective management organizations registered in Hungary for the requested mode of use;

(c) Searching databases available on the Internet;

(d) Searches of public databases suitable to find the residence of the authors;

(e) Searches of databases of publicly accessible collections of works;

${ }^{95}$ Mihaly Ficsor, How to deal with orphan works in the digital world? An introduction to the new Hungarian legislation on orphan works, Presentation to European Parliament, October 2009 at:

http://www.europarl.europa.eu/document/activities/cont/200911/20091117ATT64717/20091117ATT647 17EN.pdf.

96 Aniko Gyenge, Hungarian Ministry of Justice and Law Enforcement, Head of Unit on Consumer Protection, Copyright and Industrial Property Unit The Hungarian Model of Licensing Orphan Works, Presentation at the European States Presidency Conference on Digitisation of Cultural Material, Digital Libraries and Copyright, March 14, 2010, Madrid at: http://www.mcu.es/principal/docs/MC/PresidenciaUE2010/Aniko_Gyenge presentation.pdf.

${ }_{97}$ Decree 100/2009 (V.8.) Korm. of the Government on the Detailed Rules Related to the Licensing of Certain Use of Orphan Works, Article 2, http://www.wipo.int/wipolex/en/text.jsp?file_id=242073.

${ }^{98} I$. ., Article 2(2).

${ }^{99}$ Id. Article 3. 


\section{Diligent Search Under Present and Proposed Orphan Works Regimes}

(f) Making requests for information from organizations engaged in publishing works on a regular basis, from persons carrying out some other use of the work, as well as from public authorities performing official functions in relation to the work; and

(g) Placing advertisements in national daily newspapers.

This list of measures is non-exhaustive and is not intended to constitute a minimum or maximum threshold. The HPO determines what is sufficient to constitute a diligent search on a case-by-case basis. Taking all the measures listed may not constitute a diligent search in particular circumstances; similarly, a search may be considered diligent even when all the steps have not been undertaken. ${ }^{100}$ Finally, for works where the first publication of the work was not in Hungary the regime requires these search measures to be undertaken also in the country where the work was first published, unless it would create "disproportionate difficulties." 101

The Hungarian Patent Office is required to maintain a publicly accessible register of licenses that have been granted to use orphan works. ${ }^{102}$ To date, 22 applications for licenses appear on this Register. ${ }^{103}$ Some of these cover multiple orphan works. For example, the National Audiovisual Archive sought a license to use 370 orphaned works and the Library of the Hungarian Parliament sought a license to use about 1000 orphaned works. ${ }^{104}$

\section{Society of American Archivists Orphan Works Best Practices}

In another private effort to develop search guidelines, in 2009, the Society of American Archivists (SAA) crafted their own Orphan Works; Statement of Best Practices. ${ }^{105}$ Produced in the context of the most recent proposed U.S. legislation on orphan works (which would have required a "reasonably diligent search"), ${ }^{106}$ the SAA document "describes what professional archivists consider

100 Gyenge, supra note 97, at 5.

101 Decree 100/2009 (V.8.) Korm, supra, note 98, Art. 3(2).

102 Decree 100/2009 (V.8.) Korm., supra note 98, Art. 8.

103 Szellemi Tulajdon Nemzeti Hivatala - Árva múvek nyilvántartása (licenses through Oct. 2, 2012), http://sztnh.gov.hu/szerzoijog/arva/ARVA-muvek-nyilvantartas teljes.pdf.

${ }^{104}$ Gyenge, supra note 97 , at 8 .

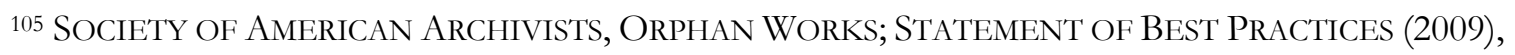
http://www.archivists.org/standards/OWBP-V4.pdf.

${ }^{106} I d$. at 1 (citing the Orphan Works Act of 2008 (H.R. 5889) and the Shawn Bentley Orphan Works Act of 2008 (S.2913)). 


\section{Diligent Search Under Present and Proposed Orphan Works Regimes}

to be best practices regarding reasonable efforts to identify and locate rights holders." ${ }^{107}$ The Statement focuses on unpublished works, though it acknowledges that the search techniques it describes may be useful in locating rightsholders of published materials as well. ${ }^{108}$

In terms of factors affecting the search, the Statement recognizes that different circumstances may require different levels of effort. ${ }^{109}$ For instance, it explains that older works require less effort than newer works, and that works to be used widely would ordinarily require more effort than those to be used narrowly. While the statement does not explain precisely how and when those factors come into play, it does explain in more detail the range of steps that could be taken to answer three central questions: "Who created the work? Who owns the work now? And where is that owner located now?" ${ }^{110}$ In locating rightsholders, the document describes what databases one might look to, what search strings to try, what other types of non-electronic resources to examine, professional membership organizations to inquire with, and other options like hiring a genealogical researcher or other experts. While subsequent users seem to agree that engaging in all the steps identified in the Statement would not be reasonable in all, or even most, cases, ${ }^{111}$ the document offers a series of practical steps one might undertake when searching for rightsholders.

\section{Orphan Works Best Practices for Libraries, Archives, and Other Memory Institutions}

Finally, there we highlight one ongoing effort to develop best practice guidelines for libraries, archives, and other memory institutions that seek to make uses of orphan works. In some ways building off of private initiatives like the SAA Statement, this project seeks to develop a set of best practices guidelines that would help individuals in these institutions understand the accepted norms within the community for when and how a search for rightsholders should be conducted. ${ }^{112}$ David Hansen and Jennifer Urban, two of the authors of this paper, are co-researcher on this project and participated in the drafting of the report that explains the goals of the project. That

${ }^{107}$ Id. at 1.

${ }^{108} I d$.

$109 I d$. at 4 .

${ }^{110} I d$. at 4.

111 See REPORT ON ORPHAN WORKS CHALLENGES FOR LIBRARIES, ARCHIVES AND OTHER MEMORY InstiTUtions 9 (Jan. 2013, Principal Researchers: Jennifer Urban, David Hansen, Pat Aufderheide, Peter Jaszi, and Meredith Jacob), http://centerforsocialmedia.org/sites/default/files/documents/report on orphan works challenges.pdf. ${ }_{112} \mathrm{Id}$. 


\section{Diligent Search Under Present and Proposed Orphan Works Regimes}

initial report explicitly takes into account the fair use argument for access to orphan works in some circumstances, ${ }^{113}$ and it is expected that the resulting best practice document will therefore focus on factors important to the fair use analysis. While the development of the best practices themselves is ongoing, it is worth noting that this and similar community-led initiatives may also play an important role in giving definition to any search standards that are more formally adopted in the United States.

\section{Conclusion}

All orphan works regimes need a way to identify which set of works will be subject to its provisions. As this survey shows, the nature and extent of search requirements in both existing and proposed orphan works regimes can vary greatly. These regimes differ in terms of the search standard itself (e.g., reasonable diligence, reasonable efforts, considerable efforts, or due diligence), the arbiter of that search standard (e.g., independent user evaluation, central government approval, or some other entity), and the level of specificity provided in the proposed statute or regulation regarding the definition of the search standard, and the set of sources to which searchers must look. The costs and benefits of each approach are far from clear. Therefore, we recommend that policy makers carefully study and encourage additional outside research on the relative merits of each approach.

113 See Jennifer M .Urban, How Fair Use Can Help Solve the Orphan Works Problem, 27 BERKELEY TECH. L.J. (forthcoming 2013), available at http://ssrn.com/abstract=2089526. 
Diligent Search Under Present and Proposed Orphan Works Regimes

\begin{tabular}{|c|c|c|c|c|c|c|c|}
\hline Regime & Search Standard & $\begin{array}{l}\text { Government approved minimum } \\
\text { search criteria? }\end{array}$ & $\begin{array}{l}\text { Who is } \\
\text { responsible } \\
\text { for search? }\end{array}$ & $\begin{array}{l}\text { Approval or review } \\
\text { of search required? }\end{array}$ & $\begin{array}{l}\text { Limits on type of users } \\
\text { or uses? }\end{array}$ & $\begin{array}{l}\text { When is } \\
\text { search } \\
\text { conducted? }\end{array}$ & $\begin{array}{l}\text { Where is search } \\
\text { conducted? }\end{array}$ \\
\hline $\begin{array}{l}\text { US Copyright } \\
\text { Office } \\
\text { approach }\end{array}$ & $\begin{array}{l}\text { "good faith, } \\
\text { reasonably } \\
\text { diligent search" }\end{array}$ & $\begin{array}{l}\text { No, but did identify set of relevant } \\
\text { factors; contemplates creation of } \\
\text { external guidelines and best practices } \\
\text { with user groups }\end{array}$ & User & $\begin{array}{l}\text { Only subject to. } \\
\text { judicial review if } \\
\text { lawsuit arises }\end{array}$ & No & Before use & Unspecified \\
\hline $\begin{array}{l}\text { US Orphan } \\
\text { Works bills }\end{array}$ & $\begin{array}{l}\text { "good faith } \\
\text { reasonably } \\
\text { diligent search" } \\
\text { and also must be } \\
\text { "reasonable and } \\
\text { appropriate" } \\
\text { under the facts }\end{array}$ & $\begin{array}{l}\text { Yes; created through agency } \\
\text { rulemaking, could incorporate industry } \\
\text { developed guidelines }\end{array}$ & User & $\begin{array}{l}\text { Only subject to. } \\
\text { judicial review if } \\
\text { lawsuit arises }\end{array}$ & No & $\begin{array}{l}\text { Before use; } \\
\text { search must } \\
\text { be } \\
\text { conducted } \\
\text { "reasonably } \\
\text { proximate" } \\
\text { to time of } \\
\text { use }\end{array}$ & Unspecified \\
\hline $\begin{array}{l}\text { EU Orphan } \\
\text { Works } \\
\text { Directive }\end{array}$ & $\begin{array}{l}\text { "diligent search" } \\
\text { in "good faith" } \\
\text { and must consult } \\
\text { "appropriate } \\
\text { sources" }\end{array}$ & $\begin{array}{l}\text { Yes; Must consult sources determined } \\
\text { by EU Member States' national laws, set } \\
\text { in consultation with rightsholders and } \\
\text { users, which much include sources } \\
\text { listed in Annex to Directive. } \\
\text { Contemplates different sources } \\
\text { depending on different classes of } \\
\text { works. Encourages consultation of } 2008 \\
\text { EU sector-specific guidelines }\end{array}$ & User & No & $\begin{array}{l}\text { Yes; only public cultural } \\
\text { institutions for non- } \\
\text { commercial } \\
\text { reproduction and } \\
\text { making available of } \\
\text { certain EU works. No } \\
\text { ongoing use in a } \\
\text { derivative work without } \\
\text { consent of reappearing } \\
\text { rightholder. }\end{array}$ & Before use & $\begin{array}{l}\text { EU member state where } \\
\text { first publication or } \\
\text { broadcast or if } \\
\text { unpublished, in country } \\
\text { where institution } \\
\text { located, but could } \\
\text { extend elsewhere if } \\
\text { evidence supports }\end{array}$ \\
\hline $\begin{array}{l}\text { Canadian } \\
\text { Regime }\end{array}$ & $\begin{array}{l}\text { "reasonable } \\
\text { efforts" }\end{array}$ & $\begin{array}{l}\text { No. Copyright Bd has the authority to } \\
\text { create but has not done so yet; } \\
\text { Copyright Bd practice is to look at } \\
\text { factors similar to those in US Copyright } \\
\text { Office Report and expects searches of } \\
\text { repertoires of copyright licensing } \\
\text { agencies and collective societies, and } \\
\text { national libraries' indices, copyright } \\
\text { offices' regn records, publishing houses } \\
\text { and corporate records. }\end{array}$ & User & $\begin{array}{l}\text { Yes; must satisfy } \\
\text { review by Copyright } \\
\text { Bd. Subject to } \\
\text { licensing fees. }\end{array}$ & No & $\begin{array}{l}\text { Before } \\
\text { agency } \\
\text { grants } \\
\text { license }\end{array}$ & $\begin{array}{l}\text { Canada, but could } \\
\text { extend if probability that } \\
\text { owner is elsewhere }\end{array}$ \\
\hline Korean Regime & $\begin{array}{l}\text { "considerable } \\
\text { efforts" }\end{array}$ & $\begin{array}{l}\text { Yes; must send notice to CMO or other } \\
\text { authorized users, and publish prior } \\
\text { notice of intended use in nat'I } \\
\text { newspaper or on websites of Ministry } \\
\text { of Culture, Sports \& Tourism and } \\
\text { Korean Copyright Commission }\end{array}$ & User & $\begin{array}{l}\text { Yes; must satisfy } \\
\text { review by Ministry } \\
\text { of Culture, Sports \& } \\
\text { Tourism. Subject to } \\
\text { licensing fees. }\end{array}$ & No & $\begin{array}{l}\text { Before } \\
\text { agency } \\
\text { grants } \\
\text { license }\end{array}$ & Unspecified \\
\hline
\end{tabular}


Diligent Search Under Present and Proposed Orphan Works Regimes

\begin{tabular}{|c|c|c|c|c|c|c|c|}
\hline Regime & Search Standard & $\begin{array}{l}\text { Government approved minimum } \\
\text { search criteria? }\end{array}$ & $\begin{array}{l}\text { Who is } \\
\text { responsible } \\
\text { for search? }\end{array}$ & $\begin{array}{l}\text { Approval or review } \\
\text { of search required? }\end{array}$ & $\begin{array}{l}\text { Limits on type of users } \\
\text { or uses? }\end{array}$ & $\begin{array}{l}\text { When is } \\
\text { search } \\
\text { conducted? }\end{array}$ & $\begin{array}{l}\text { Where is search } \\
\text { conducted? }\end{array}$ \\
\hline $\begin{array}{l}\text { Japanese } \\
\text { Regime }\end{array}$ & "due diligence" & Yes & User & $\begin{array}{l}\text { Not clear; } \\
\text { compulsory license } \\
\text { regime but } \\
\text { applicant must } \\
\text { submit info on } \\
\text { search conducted to } \\
\text { Comm'n of Agency } \\
\text { for Cultural Affairs. } \\
\text { Subject to licensing } \\
\text { fees. }\end{array}$ & $\begin{array}{l}\text { Only applies to works } \\
\text { made available in Japan } \\
\text { for some time. Copies of } \\
\text { OW must bear indication } \\
\text { that work is licensed } \\
\text { under OW regime, and } \\
\text { note date license } \\
\text { granted. }\end{array}$ & $\begin{array}{l}\text { Before } \\
\text { agency } \\
\text { grants } \\
\text { license }\end{array}$ & Unspecified \\
\hline $\begin{array}{l}\text { EU Proposed } \\
\text { CMO Directive }\end{array}$ & $\begin{array}{l}\text { "diligent and } \\
\text { good faith } \\
\text { reasonable } \\
\text { measures" }\end{array}$ & $\begin{array}{l}\text { Yes. Must verify CMO membership } \\
\text { records, and make available to CMO } \\
\text { members and to general public a list of } \\
\text { works for which rtholders not identified } \\
\text { or located. }\end{array}$ & $\mathrm{CMO}$ & $\begin{array}{l}\text { No; but subject to } \\
\text { external scrutiny } \\
\text { because CMOs must } \\
\text { publish annual } \\
\text { transparency report }\end{array}$ & Applies only to EU CMOs & $\begin{array}{l}\text { After use, } \\
\text { upon } \\
\text { distribution } \\
\text { of license } \\
\text { fees within } \\
12 \text { months of } \\
\text { financial year } \\
\text { in which } \\
\text { revenue } \\
\text { collected. }\end{array}$ & $\mathrm{EU}$ \\
\hline UK Proposal & "diligent search" & $\begin{array}{l}\text { Yes, new agency will issue sector- } \\
\text { specific guidelines }\end{array}$ & $\begin{array}{l}\text { User for } \\
\text { individual } \\
\text { uses; } \\
\text { cultural } \\
\text { institution or } \\
\text { CMO for } \\
\text { mass } \\
\text { digitization } \\
\end{array}$ & $\begin{array}{l}\text { Yes, for individual } \\
\text { uses; for } E C L \text {, } \\
\text { cultural institutions } \\
\text { or CMOs would be } \\
\text { audited for } \\
\text { compliance }\end{array}$ & $\begin{array}{l}\text { Covers commercial and } \\
\text { non-commercial uses; } \\
\text { Non-exclusive license to } \\
\text { use individual OW in UK. } \\
\text { Subject to licensing fees. }\end{array}$ & $\begin{array}{l}\text { Before grant } \\
\text { of license to } \\
\text { use or mass } \\
\text { digitization. }\end{array}$ & $\begin{array}{l}\text { Will include at least EU } \\
\text { OW Directive Annex } \\
\text { sources, and likely UK } \\
\text { Copyright Hub \& Digital } \\
\text { Copyright Exchange } \\
\text { records }\end{array}$ \\
\hline $\begin{array}{l}\text { Hungarian } \\
\text { Regime }\end{array}$ & $\begin{array}{l}\text { "appropriate } \\
\text { measures" in } \\
\text { manner deemed } \\
\text { reasonable given } \\
\text { class of work and } \\
\text { proposed use }\end{array}$ & $\begin{array}{l}\text { Yes, Sector-specific guidelines and non- } \\
\text { exhaustive list of resources deemed" } \\
\text { reasonable" included in statutory } \\
\text { regulation }\end{array}$ & $\begin{array}{l}\text { User for } \\
\text { individual } \\
\text { uses; } \\
\text { CMO for uses } \\
\text { covered by } \\
\text { existing } \\
\text { collective } \\
\text { management } \\
\text { regime }\end{array}$ & $\begin{array}{l}\text { Yes for individual } \\
\text { uses seeking license } \\
\text { from Hungarian } \\
\text { Patent Office; }\end{array}$ & $\begin{array}{l}\text { Covers both commercial } \\
\text { and non commercial } \\
\text { uses. Subject to fees } \\
\text { (waivable for non- } \\
\text { commercial). No } \\
\text { derivative works for } \\
\text { individual uses }\end{array}$ & $\begin{array}{l}\text { Before grant } \\
\text { of license to } \\
\text { use }\end{array}$ & $\begin{array}{l}\text { Contemplates Internet } \\
\text { searches; Hungary or } \\
\text { other country of first } \\
\text { publication for text } \\
\text { unless "disproportionate } \\
\text { difficulties". }\end{array}$ \\
\hline
\end{tabular}




\section{APPENDIX \\ SOURCES WHICH MUST BE CONSULTED IN A DILIGENT SEARCH UNDER THE 2012 EU ORPHAN WORKS DIRECTIVE}

Article 3(2) of the EU Orphan Works Directive provides that the decision as to what sources will be considered appropriate for diligent searches for particular categories of works is to be determined by EU Member States, in consultation with rightsholders and users, but should include at least the sources specified in the Annex to the Directive. These are set out below.

\section{ANNEX TO THE DIRECTIVE}

(1) For published books: institutions;

(a) Legal deposit, library catalogues and authority files maintained by libraries and other

(a) The publishers' and authors associations in the respective country;

(b) Existing databases and registries, WATCH (Writers, Artists and their Copyright Holders), the ISBN (International Standard Book Number) and books in print databases;

(c) The databases of the relevant collecting societies, in particular reproduction rights organisations;

(ca) Sources that integrate multiple databases and registries, including VLAF (Virtual International Authority Files) and ARROW (Accessible Registries of Rights Information and Orphan Works).

(2) For newspapers, magazines, journals and periodicals:

(a) The ISSN (International Standard Serial Number) for periodical publications;

(b) Indexes and catalogues from library boldings and collections;

(ba) Legal deposit;

(bb) The publishers associations and the authors and journalists associations in the respective country;

(bc) The databases of relevant collecting societies including reproduction rights organisations.

(4) For visual works, including fine art, photography, illustration, design, architecture, sketches of the latter 


\section{Diligent Search Under Present and Proposed Orphan Works Regimes}

works and others that are contained in books, journals, newspapers and magazines or other works:

(a) The sources referred to in points (1) and (2);

(b) The databases of the relevant collecting societies in particular for visual arts and including reproduction rights organisations;

(c) The databases of picture agencies where applicable.

(5) For audiovisual works and phonograms:

(a) Legal deposit;

(aa) The producers' associations in the respective country;

(b) Databases of film or audio heritage institutions and national libraries;

(c) Databases with relevant standards and identifiers such as ISAN (International Standard Audiovisual Number) for audiovisual material, ISWC (International Standard Music Work Code) for musical works and ISRC (International Sound Recording Code) for phonograms;

(d) The databases of the relevant collecting societies in particular for authors, performers, phonogram producers and audiovisual producers;

(da) Credits and other information appearing on the work's packaging;

(db) Databases of other relevant associations representing a specific category of rightholders.

\section{SECTOR-SPECIFIC DILIGENT SEARCH GUIDELINES DEVELOPED BY THE EU HIGH LEVEL EXPERT GROUP ON DIGITAL LIBRARIES}

Recital 14 of the EU Orphan Works Directive suggests, but does not require, that EU Member States could consult the 2008 sector-specific Diligent Search Guidelines developed by the EU High Level Expert Group on Digital Libraries established under the i2010 Digital Libraries initiative. ${ }^{114}$ These are set out below.

\section{Common resources for all sectors to identify and/or locate the rightholder(s), as feasible:}

${ }^{114}$ See http:/ / ec.europa.eu/information society/activities/digital libraries/doc/hleg/orphan/guidelines.pdf, as adopted by the Memorandum of Understanding on Diligent Search Guidelines for Orphan Works, dated 4 June 2008, at:

http://ec.europa.eu/information society/activities/digital libraries/doc/hleg/orphan/mou.pdf 


\section{Diligent Search Under Present and Proposed Orphan Works Regimes}

- Check the European Digital Library whether the work has already been digitised, including cooperation between similar cultural institutions Check. files/sources on provenance

- Credits and other title/work/ rightholder information appearing on the work's cover, packaging or otherwise (including names, titles, date and place of recording, publishing)

- Information beld in receipts, registers, files, collections management systems and other information beld by the institution

- Following up of these leads to find additional right holders (e.g., contacting a record producer to find the performers)

- Collective rights management organisations for the relevant sector and their databases

- Relevant associations or institutions representing the relevant category of right holder(s) (including unions, trade associations, their members and their databases and membership lists).

- General databases on rightholders and/or works, such as the WATCH database - www.watch-file.com

- Online copyright registration lists (including those maintained by government agencies such as the U.S. Copyright Office)

- The legal deposit/national library or archive, or other documentation centres

- Relevant personal and/or business directories and search engine searches

- The national bibliography or material relevant for the subject matter and published indexes of published material

- Published indexes and catalogues from library boldings and collections

- Published biographical resources for authors

- Published sources on the history of relevant legal bodies (such as publishers or producers having issued the work)

- Legal sources such as company house records or industry specific records/databases on change of ownership of the legal person or publication or their insolvency/winding up

- Contact other owners of the same or similar works by same author/creator

- Agencies administering relevant standards and identifiers (inter alia ISBN for books, ISSN for periodical publications, IS AN for audiovisual material, ISMN for sheet music, ISWC for musical works, ISRC for sound recordings etc.) ${ }^{115}$ [Footnote 3$]$ and their databases

- Additional publicly available sources depending on the country and the works in question such as probate records (to trace authors' beirs)

- Public Lending Right authority databases where available

- Lists of books in print

Examples of resources specific to certain subject matter

$\underline{\text { Books }}$

- Public Lending Right authority databases where available

115 ISBN: international standard book number, IS AN: international standard audiovisual number, ISMN: international standard music number, ISSN: international standard serial number, ISWC: international standard music work code, ISRC: International Sound Recording Code 4 http:/ / www.stm-assoc.org/home/stm-alpsp-psp-issue-clear-rules-for-orphan-works.html 


\section{Diligent Search Under Present and Proposed Orphan Works Regimes}

- Lists of books in print

Journals

Please refer to the Safe Harbour Provisions for the Use of Orphan Works for Scientific, Technical and Medical Literature by STM/ALPSP/PSP. ${ }^{116}$

Sheet music

Websites listing music publishers \& sheet music available in the respective countries

- Published sources on the bistory of relevant music \& lyrics writing, such as lyrics in print

Audiovisual material

- National film archives (investigation/identification of material held by such archives is part of the mission of these institutions)

- Registre public de la Cinématographie et de l'Audiovisuel, maintained by the Centre national de la Cinématographie (www.cnc.fr)

- Published filmographies (although these only record the original production company)

- In relation to underlying content, the organisations representing their rightholders, including CMOs

- (State) bodies providing financial support for the audiovisual sector

\section{Visual material, including photography}

- National projects to list known authors / creators

- www.vci-registry.org

- www.onlineart.info

116 See http://www.stm-

assoc.org\%2F2007_11_01_Safe_Harbor_Provisions_for_the_Use_of_Orphan_Works.doc 